\title{
Self-Love in Logic-Based Therapy
}

\section{Ivan Guajardo}

\begin{abstract}
The phenomenon of self-love elicits conflicting reactions. Some believe is the key to happiness, while others are skeptical. This essay defines self-love as wholehearted concern for one's well-being, argues that it does not imply selfishness, arrogance, or vanity, discusses reasons to value self-love, and describes ways Logic-Based Therapy can be used to help people love themselves.
\end{abstract}

Keywords: Self-love, W ell-Being, Wholeheartedness, Philosophical Therapy and Consultation

\section{Introduction}

$\mathrm{T}$ he phenomenon of self-love elicits conflicting reactions. Some believeis the key to happiness, but this view may rely on discourses that reduce self-love to self-acceptance, commodified notions of self-care, or mere affirmation s of uniqueness and potential for greatness. ${ }^{1}$ Others view self-love skeptically because they consider it to be selfish, arrogant, or vain. ${ }^{2}$ This essay sides with those who believe that self-love is necessary for well-being and presents a plausible picture of what self-love looks like at its best-one that can function as a guiding ideal in people's efforts to love themselves - and that philosophical therapists can use to help them. I present this picture in the first part of the essay. Using Erick Fromm's definition of love as "active concern for the life and growth of that which we love"3, I first claim that self-love implies active concern for one's wellbeing, which I articulate more precisely by taking a closer look at the notions of "well-being" and "caring" embedded in this definition. A close examination of these two notions suggests that "actively caring for one's well-being" demands attentiveness, competence, responsibility, and responsiveness to those things that enable a person to experience meaning and satisfaction. Yet being attentive, competent, responsible, and responsive to those things that allow one to experience meaning and satisfaction is not enough to explain fully the specific character of selflove. The reason is that one can imagine someone who actively cares about their well-being but lacks firm commitment to the pursuit of their true interests-what philosopher $\mathrm{Harry} \mathrm{G}$. Frankfurt calls wholeheartedness-accordingly, I add Frankfurt's condition of wholeheartedness to the ideal picture of self-love that I present in this part. The result is an ideal picture of self-love as wholehearted concern for one's well-being.

In the second part, I address skeptical worries that self-love is, or can easily degenerate into, egoism, arrogance, and vanity. I define egoism as favoring oneself at the expense of others, 
arrogance as excessive and overbearing pride, and vanity as greed for the admiration and envy of others, and then show that these excessive demands on behalf of the self are ineffective, selfdefeating forms of demonstrating concern for one's well-being.

The third part begins by giving two reasons to value self-love. The first reason is that respect for one's humanity demands it. The second reason is that it is not possible to live a meaningful and satisfying life if one is indifferent to one's own well-being. After this discussion, I offer different ways that philosophical practitioners can use Logic-Based Therapy_-the modality of philosophical practice developed by Dr. Elliot D. Cohen-to help people deficient in self-love, and people suffering from egoism, arrogance, and vanity. Some might still worry about the desirability of recommending self-love to people. The reason is that it is hard, if not impossible, to firmly devote ourselves to our interests. In the conclusion I reply to this objection —not by way of denying that wholeheartedness is rare and hard to maintain — but, instead, by suggesting ways that philosophical practitioners can help people build their willpower.

\section{Self-love as Wholehearted Concern for One's Well-Being}

The social psychologist Erich Fromm once said that love is an "active concern for the life and growth of that which we love."4 Fromm's idea is that, at its best, love entails deliberate efforts to protect the life and advance the well-being of the beloved. If Fromm's characterization is right, which I believe it is, it follows that an essential property that self-love shares with other forms of love is that, at their best, they all require deliberate efforts to protect the life and advance the wellbeing of the beloved. Like other forms of love, self-love comes in degrees, but the intention in this part of the essay is to present a plausible picture of what self-love looks like at its best, one that can function as a guiding ideal in people's efforts to love themselves. This requires a closer examination of the ideas of "well-being" and "caring" to articulate more precisely what is involved in actively caring for the well-being of the beloved. After this, I will argue that self-love requires wholehearted devotion to what we love.

The most influential theories of well-being in philosophy and psychology are hedonism, desired-based theories, life-satisfaction theories, A ristotelian eudaimonism, and network theory. ${ }^{5}$ Hedonism identifies well-being with the life of enjoyment, conceived as one composed of more pleasure than pain. To quote a recent hedonist: "what makes a life good for the one who lives it is that it contains a lot of enjoyment, or attitudinal pleasure, and relatively little disenjoyment, or attitudinal pain." 6 Desired-based theories object that well-being can exist even if pain dominates pleasure, as long as the person is able to satisfy important personal preferences. W ell-being in this sense is the condition of a life that fulfills actual or informed desires. ${ }^{7}$ A ristotelian Eudaimonism and the psychological versions it has inspired repudiate hedonism and desired-based theories on the grounds that both imply that well-being is compatible with fulfilling inappropriate desires or pleasures. A ristotelian Eudaimonism instead stresses growth and human fulfillment construed as the striving to flourish or actualize one's human potential. ${ }^{8}$ Life-satisfaction theories take issue with A ristotelian eudaimonism on the grounds that its requirements are either too idealistic, or 
specific, to be within reach of ordinary people (e.g., Aristotle's requirement of complete virtue). For this and other reasons their advocates define well-being alternatively as overall satisfaction with one's life. ${ }^{9}$ Valerie Tiberius endorses this idea and explains it as follows: "well-being is satisfaction with one's overall conditions of life evaluated on the basis of standards provided by one's values." ${ }^{\text {"10 }}$ Network Theory is the last alternative (Bishop 2015; Lang 2017). It explains what it calls "the structure and dynamics" of well-being; that is to say, its shape and the factors that engender and maintain it. Network Theory describes the structure of well-being as a positive and resilient causal network of mutually supportive, self-sustaining clusters of positive affects (e.g., feelings, moods, emotions), attitudes, traits, interactions, and accomplishments like strong relationships, professional success, and fulfilling projects. Called "PCNs", these causal networks can be established, maintained, and strengthened if basic human needs are met (prerequisites), individuals are able to pursuit their main interests (essentials), are exposed to experiences that strengthen their existing network e.g., being recognized by peers or congratulated by relatives (enhancers), and inhabit environments that promotewell-being, like ones with good schools. ${ }^{11}$

I will not endorse any of these theories but instead describe their points of agreement, since this is sufficient to make more apparent the specific character of self-love. All these theories consider well-being an enduring condition of being human rather than a fleeing or transitory moment in a person's life. All claim is a good condition, since it involves either positive affect, attitudes, growth, traits, successes, or engagements with the world. All posit prerequisites for establishing, maintaining, or enhancing this condition; in particular, being able to meet basic human needs and enjoy the support of others and society. All stress that well-being requires behaving and living in ways that align either with central pleasures, preferences, or personal valuecommitments. They disagree on the extent to which well-being is compatible with ignorance, illusion, error, and immorality, nevertheless, all these theories recognize that personal interests must be informed, authentic, and consistent with common sense moral principles.

Five characteristics of well-being are discernable in these points of agreement. Positivity. W ell-being involves states of mind that feel good, states (mental or not e.g., strong relationships) that tend to bring about states of mind that feel good, and states (mental or not) the person values. Persistence. When a life has well-being, these positive states function as components of an enduring and resilient condition instead of being disconnected or random episodes. Individuality. Personal well-being requires living a life that authentically reflects one's personality and value commitments. This subjective foundation must be as informed as possible, and appropriate, by which I mean consistent with common sense moral principles. ${ }^{12}$

Individuals experience well-being to the extent that they are living a life that has this structure. This indicates that actively caring about a beloved's well-being involves making concerted efforts to do what is within our power to ensure they enjoy this sort of life. Let us continue our analysis of "actively caring about the beloved's well-being" with a closer look at the act of caring. I will employ Joan C. Tronto's four phases of caring to make this analysis. ${ }^{13}$ 
Tronto construes caring as "a mental disposition of concern and the practices people engaged in as a result of this concern" and proposes four phases: 1 . caring about, 2. caring for, 3 . caregiving, and 4. care-receiving. ${ }^{14}$ Caring about involves becoming aware of the need for care and showing attentiveness or the ability to accurately perceive needs and prioritize them well. Caring for is the act of assuming responsibility for meeting the needs that have been prioritized. Caregiving involves the necessary caring tasks that must be performed to address them. Good caregiving assumes that those responsible for performing the care tasks are competent or know what they are doing. Caregivers must also be attentive to how those under their care are responding to the care they are receiving. Tronto calls this fourth dimension "care-receiving."15

Tronto's analysis of the process of caring does not assume that caregivers love those under their care. Business owners normally do not love their costumers, masters their pupils, nurses their patients, or teachers their students. People in these and other service professions can be attentive, responsible, competent, and responsive to the needs or preferences of those under their care without regarding them in the way that love demands. Love is a mode of caring but is not synonymous with it. It implies emotional attachment and -at least when pure - valuing the beloved in a disinterested manner i.e., without any ulterior motives, as a final end, rather than as a means to securing some other benefit. It also involves identification with the beloved's wellbeing. Lovers experiencethegood or bad that happens to their loved ones as happening to themnot just to someone for whom they feel sympathy or is under their care. They benefit or suffer depending upon whether the interests of their loved ones are ad equately served, one of the reasons love necessarily makes people vulnerable. Finally, unlike caring without loving, love is not fully within our control. What people love is largely contingent on genetic and environmental influences not amenable to their will. ${ }^{16}$ As Frankfurt explains: "love is determined by conditions that are outside our immediate voluntary control."17

Despite these important differences, Tronto's explanation of the process of caring helps us grasp better what goes into actively caring for someone we love. Active caring requires attentiveness to their needs and values i.e., the activities, relationships, goals, aims, ideals, and principles that they care about. Whether it ends up being effective partly hinges on luck and other factors outside the lover's control, yet actively caring for a beloved's well-being entails assuming theresponsibility to do whatever is within one's power to identify and advance their true interests. Ongoing responsiveness to the effectiveness of one's efforts is also needed to gauge whether these efforts are indeed protecting and advancing the beloved's good. It is unlikely that this will be the case if our efforts are grounded in false or ill-informed beliefs; for instance, false or ill-informed beliefs about the beloved's needs or what really matters to them. For this reason, effective love demands efforts guided by well-informed beliefs and values. To be sure, it is hard to develop and maintain well-informed beliefs and values. Nevertheless, a person is more likely to do so by being flexible, open to change, hence willing to revise their assumptions if feasible and warranted. In other words, effective love demands responsiveness. 
The same is true of actively caring for one's well-being. Just like actively caring about other people's well-being requires attentiveness to their needs and values, doing so in our own case requires attentiveness to our needs and values i.e., the activities, relationships, goals, aims, ideals, and principles that fundamentally matter to us. Self-attentiveness means being mindful of oneself in order to determine one's basic needs and values "with as little distortion as possible" and make important decisions on their basis. ${ }^{18}$ Achieving and maintaining well-being partly hinges on luck and other factors outside one's control, yet actively caring for one's well-being just like actively caring for another person's well-being —entails assuming the responsibility to do whatever is within one's power to behave and live in a way that is conducive to meeting one's basic needs and cultivating what really matters to us. This is unlikely to happen if one relies on luck, so actively caring for oneself entails making concerted efforts to determine the sorts of actions and life-pursuits that are conducive to meeting one's basic needs and cultivating one's values. Ongoing responsiveness to the effectiveness of one's efforts is also needed to be able to gauge whether the fundamental values guiding these efforts are indeed helping us live well. Again, it is unlikely that they will do so if these values are themselves grounded in false or ill-informed beliefs about self, other, and world; for instance, false or ill-informed beliefs about one's character, or about one's relation to society. For this reason, people who love themselves care to make sure that their fundamental values are based on appropriately informed beliefs. There are no guarantees, but a person is more likely to meet this condition by being flexible, open to change, hence willing to revise their values if feasible and warranted. Self-love implies the intention to care about one's own well-being and the disposition to do so effectively. Consequently, pursuing one's interests without ceasing to be responsive to how doing so affects one's well-being overtimeand, likea good fallibilist, using this feedback to make necessary adjustments and revisions when feasible and warranted by experience, is also part and parcel of what it means to actively care for the self.

This interpretation of "actively caring for well-being" makes more evident the sense in which self-love is a form of love, but it requires supplementation to fully capture the specific character of self-love. Consider: one can imagine individuals that are aware of some of their main interests, take some responsibility to pursuit them, have someknowledge to do so, and makesome efforts to be responsive to how their attempts to cultivate them affects their well-being, but their identification with what they profess to care about is inconsistent or weakhearted. Consider the case of Juanita. Juanita wants to teach high school science. She likes biology, reads books on the subject, and enjoys teaching what she knows to her younger sister. She is currently in college pursuing a degree in biology, but she is not devoted enough to this project. When feeling opposite inclinations, she tends to doubt herself and holds back. She is ambivalent about what she wants and has been unable to take a firm stance on what side of her opposite inclinations she is on. Instead, she often finds herself procrastinating or wasting time on peripheral concerns.

It may be that Juanita's case involves someone who does not actively care about her own well-being because she is ambivalent with respect to what she wants or may not be putting enough effort to overcome her ambivalence. On this view, Juanita does not love herself or not as much 
because she is being passive. This may be true, but it seems that the problem is rather that Juanita lacks sufficient commitment, dedication, or investment in her central projects. So, unless J uanita is at least trying to develop a more firmed stance and does so at some point, we would be justified in claiming that she does not love herself, or does not love herself enough, not because she is not actively trying, but because she lacks serious devotion to her interests.

Cases like Juanita's show that defining self-love in terms of its object is not enough. An adequate description of self-love must refer also to how invested the person is in her interests. M ore precisely, it must consider how firmly invested someone is in the life-pursuits that align with their value-commitments i.e., the activities, relationships, goals, aims, ideals, and principles that they claim to be central to who they are or take themselves to be i.e., that are at the core of their self-understanding. On this interpretation, onel am borrowing from H arry G. Frankfurt, a person demonstrates love of self not just by making deliberate efforts to identify and pursuit their true interests, but also by showing resoluteness. To quote Frankfurt:

"The wholehearted person knows what he wants. With regard to any conflict of feelings or tendencies within himself, he knows where he stands. So far as his loving is concerned, he is wholeheartedly invested in it; he lends himself to it without any qualification or reserve... He is altogether wholehearted in loving what he loves...To be wholehearted is to love oneself."19

In the essay these words come from, Frankfurt points out correctly that wholeheartedness is about how involved people are with their main interests not about being narrowly focused on one of them. ${ }^{20}$ Wholeheartedness also does not imply dogmatism, inflexibility, or stubbornness, which are ways of regarding one's preferences that are detrimental to one's well-being by making one unresponsive to contradictory experiences. A person demonstrates love of self not by being single-minded or narrowly focused on one thing, or by holding on to their value-commitments come what may, but by being dear to the self or, which is the same, by earnestly investing themselves in the pursuit of those things that they profess to love or value the most.

\section{Self-Love does not imply Selfishness, A rrogance, or V anity}

I said before that love comes in degrees. Just as it is right to claim that well-intentioned parents love their children even if they ignore, are mistaken, or unsure about what's good for their children, someone who is ignorant, mistaken, or unsure about their own needs and values can be said to love themselves in so far as they are trying to figure this out. But ideally self-love entails active and wholehearted engagement in life-projects that one loves or cares about. Is it good to encourage people to love themselves? Some believe that self-love is selfish, arrogant, or vain, and may be worried that encouraging people to love themselves will only promote self-absorption. This worry is understandable. It is reasonable to claim that we are living in a narcissistic society that encourages selfish forms of self-fulfillment, a culture of self-absorption that has been made worse by social media. I wish now to address this concern by identifying and clarifying some 
important differences between caring about one's own well-being and the excessive demands on behalf of self that characterize the acts of egoism, arrogance, and vanity.

The worry that self-love is selfish or can easily degenerate into it has a long and distinguished history. The seventeen century French moralist De LA Rochefoucauld called selflove "the greatest flatterer of all flatterers." ${ }^{\text {"21 }}$ Blaise Pascal defined it as "loving only self and considering only self" and tied it to a pretentious desire to make ourselves independent of God. ${ }^{22}$ It is true that self-love requires being properly self-interested since it is motivated by the desire to live a life that is good for us and doing so demands meeting one's needs and pursuing one's values, which in turn demands the courage to favor them over the needs and interests of others and society when feasible and warranted. However, egoism goes beyond this reasonable appeal to selfinterest. Egoism refers to the tendency to favor oneself at the expense of others. Egoists assume that the world revolves around them. They believe their desires are more valuable simply because they own them. This excessive demand on behalf of self contradicts the aim of self-love. The aim of self-love is to experience well-being. It is unlikely that a person will do so sustainably if the values they are committed to are incompatible with the objective interest they have in cooperating with others, respecting their rights, and maintaining meaningful relationships. Effective pursuit of individual preferences takes into account the objective interest individuals have in being social, which requires being responsive to the legitimate demands that others and society make on individuals. Thereis no al gorithm for balancing individual interests with the demands others and society make on us, a method that would tell us consistently when we are unfairly favoring ourselves at the expense of others. Yet selfish people do not make enough efforts to achieve and maintain a reasonable balance. It is no surprising that they end up alienated from themselves, others, and the world.

People who care about themselves often feel pride and joy in being themselves. Pride is the satisfaction people experience when they or their loved ones accomplish something valuable. Pride is in order when justified and measured. The $17^{\text {th }}$ Century French philosopher Jean-Jack Rousseau and the contemporary English philosopher Simon Blackburn point out that pride plays an important role in motivating people to achieve something praiseworthy, excel, and not give up on themselves. Science links pride to altruism, wanting to get ahead but also get al ong with others, low levels of prejudice towards outgroup members, and other prosocial behaviors. This research reveals that pride is closely associated with authenticity, agreeableness, conscientiousness, and modesty. These character and personality traits make it easier for someone to achieve goals and get along with others. Pride al so fosters self-esteem..$^{23}$

Despite these positive correlations to well-being, pride can degenerate into arrogance if it becomes excessive and overbearing. A rrogant people overestimate their knowledge and value, look down upon those they consider to be inferior, resent those better than them, and are overly sensitive to perceived threats to their inflated ego. Science supports this. It shows that arrogant people overestimate their level of skill and importance, tend to be less empathetic towards 
outsiders, want unearned privileges, have fragile self-esteem, and are prone to shame. The way the arrogant deal with shame is a main reason for these tendencies. ${ }^{24}$ Shame is the fear of falling short in the eyes of others. As Simon Blackburn (2008) explains, "it is a reaction to things one fears to be sins, flaws, or faults." ${ }^{325}$ The arrogant cope with shame by pretending they are better or more knowledgeable than everyone else. This way of defending their fragile self-esteem against feelings of vulnerability is responsible for their affected comportment and causes interpersonal problems. Kant made the important observation that "arrogance is an unjustified demand that others think little of themselves in comparison with us, a foolishness that acts contrary to its own end." ${ }^{26}$ Kant's insight is that in expecting others to belittle themselves to make us look equal or better than them brings the opposite consequence of making them think less of us. For this and other unmentioned reasons, arrogance (like egoism) proves to be a self-defeating way of trying to achieve and maintain well-being because it is impossible to do so sustainably without cultivating an accurate and just appreciation of our importance and proper place in society.

Vanity is close to arrogance. Aristotle equates it with believing that one is "worthy of great things" when one is not because, like arrogance, vanity assumes that one is better or more deserving than warranted. ${ }^{27}$ It differs from arrogance in that an arrogant person may be quite and care little about what others think, while vain people tend to brag about how "great" they are to secure the admiration and envy of others. 'Vainglory', an archaic term meaning in Latin roughly "empty boasting", reflects this tendency. Vain people believe they deserve the attention and envy of others due to achievements and possessions that may be popular but that they have not earned or are not as praiseworthy as they assume. Think of someone who brags about their looks, believes others ought to admire and envy their intelligence, or boasts about having stolen an election they actually lost to a rival. Boasting about unearned or superficial achievements and possessions in order to be admired and envied by others is what these examples of envy have in common and having a taste for this has many negative effects on well-being, but the following ones strike me as the most relevant.

To have the admiration and envy of others one must cater to their opinions and prejudices, but this requires living according to the opinions of others rather than our own. Because it requires caring too much about what others think, vanity encourages people to jump into the band wagon of convention instead of identifying and expressing their individuality. This is the reason Aristotle says that vain people tend to "undertake commonly honored exploits." ${ }^{.28}$ But excessively doing this undermines one's capacity to live authentically, which is essential to live well. In a book on Self-Love, Simon Blackburn remarks that "it is not likely that someone should be prone to vanity without also being prone to envy."29 A person must experience envy before they could want others to envy them. Envy is the painful awareness that someone has an advantage that we wish we had ourselves. Envy can motivate us to attain the advantage we envy in others which can result in self-improvement if enjoying the advantage is conducive to it and is not sought at the expense of those we envy. But vain people desire the envy of others in order to maintain an unrealistic and superficially grounded opinion of themselves. Their need to be admired and 
envied is likely to be driven by insecurities that cause them to feel threatened and resentful towards those who have the advantages they wish for themselves. This limits their capacity to connect meaningfully with anyone that might threaten their social status and makes their well-being dependent on how they fair in relation to others. It also makes them vulnerable to flattery. Flattery is excessive and insincere praise, especially to further one's own agenda. Since vain people crave the adulation and envy of others, they become vulnerable to being flattered by opportunists who recognize their craving.

\section{Self-Love in Logic-Based Therapy}

At its best self-love is active concern for one's well-being and demonstrating self-love in the way one behaves and lives does not imply egoism (privileging oneself at the expense of others), arrogance (excessive and overbearing pride), or vanity (greed for the admiration and envy of others). The opposite is the case: being attentive, competent, responsible, responsive, and wholehearted about one's needs and values is closely linked to pride and self-esteem. It is time to answer two important questions: 1. Why should anyone care to love themselves? 2. What can philosophical practitioners do to help people love themselves more adequately?

Why should anyone care to love themselves? This is a valid concern. It is true that unless a person has been abused, neglected, or turned against it, they disinterestedly value living a meaningful and satisfying life. But the fact that people tend to disinterestedly value a life that is good for them to live does not mean that they should. A ssuming this is to commit the naturalistic fallacy, the mistake of thinking that something ought to be the case just because it is. Kant distinguishes between perfect and imperfect duties. Perfect duties are obligations binding on all rational beings without exception, while imperfect duties are obligations binding on all rational beings that admit of some exceptions. Setting aside the seemingly unsurmountable challenge of showing that some duties are perfect, Kant believes that we have an unqualified obligation to respect ourselves and a qualified one to develop our talents and do what we love. The obligation to respect our humanity derives from our belonging to a rational species whose members are generally able to think for themselves and exercise autonomy over their own lives. It forbids us from being servile, which happens when we treat our own and the humanity of others as a mere tool for some end that no rational being could consent to. Although I will not spend time defending it here, I agree with Kant that we have an imperfect duty to cultivate our individuality and not caring enough to do so, when there are no moral compelling reasons to set aside our wellbeing, amounts to disrespecting our humanity.

An important reason, then, to encourage others to care about their own well-being is that respect for their humanity demands it. A nother reason is that indifference towards the value of pursuing our true interests amount to indifference about living a meaningful and satisfying life. Unless one cares about one's well-being there is no motivation to commit to doing what is good for the self which is necessary to experience lasting meaning and satisfaction. In other words, as Frankfurt says, "[self-love] protects us from the emptiness and vanity of activity that is basically 
pointless because it has no definite goal and therefore aims at nothing that we really want. In other words, it makes it possible for us to engage in activity that is meaningful. The desire to love is just the desire that there be some meaning in our lives." ${ }^{\text {30 }}$

The duty we have to respect our humanity and the importance of self-love to live meaningfully and satisfyingly are not the only reasons to value and promote self-love. It also may not be possible to love others if we do not love ourselves. This is how some interpret the Christian injunction to love thy neighbor as thyself. ${ }^{31}$ But these two reasons suffice to remind us that selflove is closely linked to maintain well-being. The aim of philosophical practice is to help people address the issues that are affecting their well-being. This brings us to the second challenge: what can philosophical practitioners do to help people love themselves more adequately?

Self-love requires knowing what one needs and importantly wants, and investment in a life that aligns with it. The branch of philosophical practice that concerns itself with consulting rather than therapy can help people identify their most important values and develop a plan of life that prioritizethem over more peripheral ones. It can also help them coperationally with conflicts between these values. It would be useful to say moreabout ways this can be done, but I will instead focus on describing ways that LBT can help people that are deficient in self-love, and those that have the opposite problem and suffer from egoism, arrogance, and vanity.

LBT could help people who think too little or too much of themselves by identifying, refuting, and replacing with the right virtues the irrational beliefs built-into the emotional and behavioral reasoning informing their deficient or excessive ways of regarding themselves. I will first consider fallacies that may be affecting those who do not care enough about themselves and the virtues they will need to transcend them, and afterwards fallacies that may be affecting the selfish, arrogant, or vain, and the virtues they will need to transcend them.

I magine someone who does not care enough about themselves because they feel they do not deserve to live, be happy, or dedicate their life to doing what they value and find satisfying. LBT posits that when people have a low opinion of themselves, it is because they irrationally believe there is something wrong with them or have done something that disqualifies them from their right to life and the pursuit of happiness. ${ }^{32}$ People form these irrational beliefs typically after devaluing themselves (a fallacy called "Self-Damnation"), because they fail to meet their own selfimposed, absolute, unrealistic expectations, a species of perfectionism that Cohen calls "SelfRegarding Perfectionism." "33 To return to our example, the person we are imaging either judges their self-worth based on self-imposed, idealistic standards of achievement (Achievement Perfectionism), or approval (Approval Perfectionism), or moral performance (Moral Perfectionism). ${ }^{34}$ Their self-defeating emotional reasoning follows this pattern: "I must always or nearly al ways achieve the things that are important to me, have the approval of others, or honor my moral principles." If I fail to always or nearly always achieve the things that are important to me, have the approval of others, or honor my moral principles, I must devalue my life and person. I am failing to always or nearly always achieve the things that are important to me, secure the 
approval of others, or honor my moral principles. Therefore, I am warranted in concluding that I am inadequate or unworthy."

The key to help people overcome the self-defeating emotions and behaviors that result from turning preferences into demands for achievement, approval, and moral perfection is to expose the irrationality of these demands. This can be done in various ways; for example, by pointing out the futility of demanding perfection from imperfect beings, the absurdity of assuming that a person's worth varies with the approval of others, and the impossibility of perfect moral integrity. A fter this refutation is carried out, the philosophical practitioner must then proceed to help the person replace these irrational demands with the right dispositions.

What the person we are imagining needs the most is self-respect. Self-respect "involves unconditional self-acceptance based on a philosophical understanding of human worth and dignity."35 Unconditional self-acceptance (henceforth "USA") is the habit of taking oneself as one is and not as onethinks one should be not matter what i.e., without ever calling into question one's value as a human being - regardless of one's shortcomings. The point is that it is fallacious and self-defeating to globally rate one's life and person because of particular deeds or qualities one likes or dislikes, so USA releases people from the anxiety of putting their worthiness on the lineso they can focus on self-improvement without self-damnation. As Albert Ellis explains,

"You evaluate the efficacy of your thoughts, feelings, and actions; but you don't rate or measure your total self or efficacy. In fact, you can't because you are a changeable individual. You are not static. You grow, develop, progress-and retrogress. ${ }^{336}$

Developing the disposition to respect themselves no matter what their shortcomings should help the person we are imaging love themselves. Carl Rogers argues that when individuals learn to see themselves as they are regardless of their shortcomings, they become open to experience, start trusting themselves, and are more willing to think for themselves and make their own decisions. ${ }^{37}$ They become willing to embrace themselves when they began accepting themselves. They began moving in the direction of becoming fully functioning individuals.

LBT can also be used to help people who are selfish, arrogant, or vain. Selfish people assume that the world revolves around them. It may be natural to think this because individuals can see the world only through their own eyes, but egoism undermines a person's well-being. Assuming that the egoist we have in mind does not suffer from a personality disorder like narcissism, the way to help them become less selfish is to challenge their irrational belief that the world revolves around them, a fallacy one can see operating in the following emotional syllogism: "Major Premise: If I like, prefer, think, or value $\mathrm{X}$, then everything and everyone must do as me. M inor Premise: I live, prefer, think, or valueX. Conclusion: Everything and everyonemust behave or cater to these preferences, thoughts, or values" ${ }^{38}$ The major premise depends on the Protagorean-like assumption that a person is "the measure of all things-of things that are, that they are, and of things that are not, that they are not" 39 , which absurdly implies that individuals 
are infallible, double standards are justified, and that the egoist's preferences must be categorical imperatives simply because they own them.

Egoists need to become more objective and empathetic. Instead of assuming that others and the world must conform to their beliefs and preferences, that their own happiness is more objectively valuable simply because is theirs, they need to learn to see their own point of view as one of many other potentially valid ones that must be taken into account to be able to live in harmony with themselves, others, and the world. Put differently, they need to learn to see reality for what it is, in all its complexity, as containing other beings whose needs and preferences deserve just as much fair consideration as their own needs and preferences. Objectivity presupposes empathy. Empathy is the capacity to occupy other perspectives and connect with them cognitively, emotionally, and normatively. It is the basis of the trust, mutuality and reciprocity needed for cooperation and any other positive relationship with other individuals, society, and the world. Often egoists cannot tolerate the fact that other people disagree with them. They demand that others always or nearly al ways share in their values. This calls for tolerance. Tolerance helps us give a fair hearing to beliefs and preferences that we may not agree with. It is about refusing to take the dismissive way out and instead focus on building, "the willpower to allow independent, diverse voices to have a fair hearing, even if you don't agree with them." to be more objective, empathetic, and tolerant, egoists cannot hope to transcend the alienation from themselves, others, and world that often afflicts them, hence they need to learn these virtues if they want to live better lives.

Egoists may be arrogant as well. Arrogant people behave as if they are more important and knowledgeable than others. This presumptuous behavior may be explained by the fact that they have managed to achieve great things compared to their peers and think they are superior because of it, or they have not managed to achieve much and are consciously or unconsciously overcompensating for it by trying to appear more worthy to impress others. This suggests that arrogance expresses the belief that one's success makes one superior to others, or is a defense mechanism against shame, which is what the research I cited earlier proposes.

If the arrogant we are trying to help turns out to be someone who thinks they are superior because of their success, the challenge is to convince them with counterexamples, counterevidence, and other refutations that their sense of superiority is grounded in the following fallacious argument: "I have achieved things my peers have not or cannot achieve; therefore, I am worthier than they are, and thus justified in being conceited." This is a non sequitur because even if were true that their accomplishments entitle them to more economic and other social rewards than others, it does not follow that they entitle them to a greater bundle of moral rights and freedoms than others, and they must come to understand this if they wish to transcend their arrogance. If the arrogance is instead an affectation-a defense mechanism against the fear of being inadequate and exposing weaknesses to others-the challenge is to convince the person to stop demanding the attention and approval of others as a condition of their self-worth (approval 
perfectionism), and instead develop the courage to confront their feelings of inadequacy, learn to respect themselves unconditionally, and concentrate on building their self-confidence and selfworth by trying to achieve good things.

Either way, the person must learn the virtues of objectivity, authenticity, empathy, and modesty. Let me make some important points about modesty, since I have already made some remarks about the other ones and many believe modesty is the key to transcend arrogance.

Modesty depends on the eleven cardinal virtues that LBT recognizes; in particular, objectivity ( which in this context means having an accurate and fair view of oneself and the causes of one's accomplishments), metaphysical realism (feeling comfortable and secure being an imperfect being that lives in an imperfect universe), empathy (caringly taking the perspective of others into account), respect (unconditionally accepting oneself, others and the world), and authenticity (which is about expressing one's true self). Probably it is for this reason that LBT does not explicitly talks about modesty, but it has its own value. In some contexts, modesty means behaving and dressing decently, but I have in mind a person who is unassuming or does not like to brag about, dwell on, or make a bid deal about their good qualities and accomplishments. M odest people do not feel the need to massage their own ego, or impress others, or look down on other people, as the arrogant do to feel good and more deserving.

Arrogant people need to learn to be modest in the sense just described to enter into a better relationship with themselves, others, and the world. They may learn to do so if they are taught the importance of placing individual accomplishments in a broader context. Behaving as if one were better or more knowledgeable than others, even if this is due to having accomplished great things, underestimates the role luck and other external factors play in individual success. M odesty keeps us from doing this by helping us maintain perspective. ${ }^{41}$ This is the reason modest people are more able and willing than the arrogant to appreciate the role luck and other external conditions played in their own accomplishments. There is, of course, no guarantee that the arrogant would attend to luck and other external circumstances that contributed to his success and become more modest about his life by gaining perspective. But it is not possible to become more modest without gaining this perspective, so they need to try.

The scientific studies that were cited earlier show that arrogant people care more about their performance than the value of what they are doing or mastering the skills to serve it well. They also tend to explain their success in terms of uncontrollable, stable factors like genes and intelligence, rather than controllable, stable factors like effort. ${ }^{42}$ These tendencies indicate that arrogant people simultaneously underestimate the importance of individual effort in success and overestimate the importance of factors likegenes, talent, and other natural traits. In helping them keep perspective, modesty may teach them not only that effort is more important than these natural traits, but also that even effort is beholden to luck and external conditions. 
The arrogant may be vain also. Vain people believe that the qualities and accomplishments they brag about are more praiseworthy than warranted. They crave the admiration and envy of others, so they are more concerned to turn people's attention to theaspects of themselves they believe they should be admired or envy for, rather than the value of what they are doing, or the role others and external circumstances have played in their success. A person does not crave the admiration and envy of others unless they believe they deserve to be admired and envied, so this irrational belief must be refuted to help the person control their vanity, by challenging the reasons they think they are so great that they deserve this from others. They must also understand that their craving for the admiration and envy of others indicates that they care too much about what others think, and that they do so because they irrationally assume that selfworth depends on securing the admiration and envy of others, which in the case of vanity, is usually for aspects of oneself that may be popular but may not do justice to one's humanity. Vanity also assumes that bragging about one's qualities and role in success will make others like us. Although this may occur in some cases, more often it has the opposite effect of making others dislike us. Besides, vanity makes one vulnerable to flattery.

Like arrogant people, vain people need to internalize the virtues of self-respect-if their belief that they deserve the admiration and envy of others hides insecurities that demand the approbation of others to feel worthy_authenticity_-so they can stop jumping into the bandwagon and move in the direction of expressing their individuality_and modesty, so they can control the presumption of thinking that they are so great that other must admire them.

\section{Conclusion}

Self-love is a necessary condition to achieve and maintain well-being, a positive and enduring state of living that is achieved and maintained by identifying and pursuing one's true interests. It demands attentiveness, competence, responsibility, responsiveness, and wholehearted investment in thethings that fundamentally matter to the self. Loving the self is not about behaving and acting as if the world revolved around us, or being excessively and overbearingly proud, or greedy for the admiration and envy of others, but about being firmly committed to cultivating what one loves to live a meaningful and satisfying life of our own choosing.

Some people are deficient in self-love because they developed the irrational belief that their worthiness depends on the approval of others, or al ways achieving the things they consider important. Other people have the oppositive problem. They make excessive demands on behalf of the self because they developed the irrational belief that the world revolves around them, exaggeratetheir importance in success, use pretention to copewith shame, or areaddicted to being praised and envied by others because they falsely believe they deserve it. This essay offered ways LBT could be used to refute these irrational beliefs and replace them with the virtues of authenticity, empathy, objectivity, modesty, and self-respect. Let me end this essay with some brief remarks on an important concern that must be acknowledged. 
Self-love requires devotion to what one loves. It demands wholeheartedness or firm commitment to the pursuit of projects that are most expressive of one's value-commitments. But this is hard if not impossible. Human beings often feel uncertain and ambivalent about what they want, partly due to their psychological make up and partly due to the often conflicting demands their own values and the values of others and society place on them. It is due to considerations likethese that philosophers like H arry G. Frankfurt believethat wholeheartedness is hard and rare, that "any substantial degree... depends heavily upon luck". But if this is the case, does not this render self-love an empty ideal not worth recommending?

We must agree with Frankfurt that love is not simply a matter of choice, that is subject to conditions - like genetics and luck - that are not immediately within our control. I made this point while differentiating love from the mere act of caring. Let's acknowledge, then, what seems to be true, that for the most part humans find themselves thrown into most of their love relationships and cannot simply decide differently. They cannot just choose to love something at will _ including themselves — let alone do so wholeheartedly.

Does this render self-love an empty ideal not worth recommending? I do not think so. The good news is that unless we have been abused, neglected, or otherwise traumatized, we naturally care for our lives and the things and relationships that bring meaning and satisfaction to our lives. Philosophical practitioners can help individuals struggling to love themselves get in touch with this natural inclination and build on it. This is not sufficient to make them more wholehearted about their important preferences, but it is an important foundation for it. Practitioners can also encourage people to see wholeheartedness as a practice that one can improved upon with exercises designed to strengthen the will. After all, science and common sense tell us that the human will is a muscle that can be strengthened with intelligent effort and practice i.e., with discipline, concentration, patience, and by having reasonable faith in oneself.

Ivan Guajardo is an associate professor of philosophy in the College of Liberal A rts and Social Sciences at Virginia Western Community College, where he also serves as the faculty sponsor for the Philosophy Club and the Human Rights Club. I van works in the areas of metaphysics, philosophy applied to psychology, and ethics. 


\section{References:}

Aristotle. Nicomachean Ethics. Translated by Terence Irwin. Indianapolis/Cambridge: Hackett Publishing Company, 1985.

Bishop, Michael. The Good Life: Unifying the Philosophy and Psychology of Well-Being. Oxford: Oxford U niversity Press, 2015.

Blackburn. Simon. Mirror, Mirror: The Uses and Abuses of Self-Love. Princeton: Princeton U niversity Press, 2014.

Bommarito, Nicolas. "Modesty as a Virtue of Attention." The Philosophical Review 122(1) (2013): 93-117.

Burton, Singer. "Know Thyself and Become What You Are: An EudaimonicA pproach to Psychological W ell-Being." Journal of Happiness Studies 9 (2008): 13-39.

Claire, Ashton-James and Jessica Tracy. "Pride and Prejudice: How Feelings About the Self Influence Judgments of Others.” Personality and Social Psychology Bulletin 38(4) (2012): 466-476.

Cohen, Elliot D. What Would A ristotle Do? Self-Control Through thePower of Reason. A mherst: Prometheus Books, 2003.

Cohen, Elliott D. The New Rational Therapy: Thinking Your Way to Serenity, Success, and Profound Happiness. Lanham: Rowman \& Littlefield. 2007.

Cohen, Elliott D. Logic-Based Therapy and Everyday Emotions: A Case-Based Approach. Lanham: Lexington Books, 2016.

Cohen, Elliot D. Making Peace with Imperfection: Discover Your Perfectionism Type, End the Cycle of Criticism, and Embrace Self-Acceptance. O akland: I mpact Publishers, 2019.

De La Rochefoucauld, Francois. Collected Maxims and Other Reflections. Translated by E.H . and A.M Blackmore and Francine Giguere. Oxford: Oxford U niversity Press, 2007.

Ellis, Albert. The Myth of Self-Esteem: How Rational Emotive Behavioral Therapy Can Change Your Life Forever. Amherst: Prometheus Books, 2005.

Feldman, Fred. "The Good Life: A Defense of Attitudinal Hedonism." Philosophy and Phenomenological Research 65 (2002): 604-628.

Frankfurt, Harry G. The Reasons of Love. Princeton: Princeton U niversity Press, 2004.

Fromm, Erich. The Art of Loving. New Y ork: Harper Perennial M odern Classics, 2006.

Griffin, James. Well-Being: Its M eaning, M easurement, and Moral Importance. Clarendon: Oxford, 1986.

Hay, Louise L. You Can Heal Your Life. Carlsbad: Hay House Inc., 2004.

Kant I mmanuel. Groundwork of the M etaphysics of M orals. Translated by M ary Gregor. Cambridge: Cambridge University Press, 1998.

Kant. Immanuel. A nthropology from a Pragmatic Point of View. Edited by Robert B. Louden. Cambridge: Cambridge U niversity Press, 2006.

Kreeft, Peter. Christianity for Modern Pagans: Pascal's Pensées Edited, Outlined and Explained. San Francisco. Ignatius Press, 1993. 
Lang, M artha L. The Network Theory of W elk-Being, Revamped. Florida State University Libraries, Electronic Theses, Treatises, and Dissertations, 2017

Protagoras. A Presocratic Reader: Selected Fragments and Testimonia. Edited by Patricia Churchland. Translated by Richard D. McKirahan, Jr. Indianapolis/Cambridge, 1996.

Rogers, Carl R. On Becoming A Person: A Therapist's View of Psychotherapy. Boston: Houghton M ifflin Company, 1995.

Rousseau, Jean-Jacques. Discourse on the Origin of Inequality. Translated by Donald A. Cress. Indianapolis/Cambridge: H ackett Publishing Company, 1992.

Sumner, L.W. 1996. Welfare, Happiness, and Ethics. New Y ork: Oxford U niversity Press, 1996.

Tiberius, Valerie. "Well-being: Psychological Research for Philosophers." Philosophical Compass 1(5) (2006): 493-505.

Tiberius, Valerie. Well-Being as Value Fulfillment: How We Can Help Each Other to Live Well. Oxford: Oxford University Press, 2018.

Tracy, Jessica and Richard Robins. "The Psychological Structure of Pride: A Tale of Two Facets." Journal of Personality and Social Psychology (2007): 506-524.

Tronto, Joan C. "An Ethic of Care." Generations: Journal of American Society on Aging 22(3) (1998): 15-20.

\footnotetext{
${ }^{1}$ Louise L. Hay, You Can Heal Your Life(Carlsbad: Hay House Inc., 2004)

${ }^{2}$ Francois De La Rochefoucauld, Collected Maxims and Other Reflections, trans. E.H. and A.M Blackmore and Francine Giguere (Oxford: Oxford University Press, 2007)

${ }^{3}$ Erich Fromm, The Art of Loving (N ew York: Harper Perennial M odern Classics, 2006), 25.

${ }^{4}$ Fromm, The art of loving, 25.

${ }^{5}$ Valerie Tiberius, "Well-being: Psychological Research for Philosophers" Philosophical Compass

1(5) (2006): 493-505.

${ }^{6}$ Fred Feldman, "The Good Life: A Defense of Attitudinal Hedonism." Philosophy and

Phenomenological Research 65 (2001): 607.

${ }^{7}$ James G riffin, Well-Being: Its M eaning, M easurement, and M oral Importance(Clarendon: Oxford,1986).

${ }^{8}$ A ristotle. Nicomachean Ethics, trans. Terence I rwin (Indianapolis/Cambridge: Hackett

Publishing Company, 1985)

${ }^{9}$ L.W. Sumner, Welfare, Happiness, and Ethics. (N ew Y ork: Oxford U niversity Press, 1996)

${ }^{10}$ Tiberius, "Well-being: Psychological Research for Philosophers," 420.

${ }^{11}$ M ichael Bishop, The Good Life: Unifying the Philosophy and Psychology of Well-Being (Oxford:

Oxford U niversity Press, 2015)

12 It is beyond the scope of this essay to defend the objectivity of morality, but what I have in mind by "common sense morality", are fairly uncontroversial moral rules, like "In general, lying is wrong", "It is generally wrong to kill innocent persons", it is generally wrong to favor oneself at the expend of others", and so on and so forth.

${ }^{13}$ Joan C Tronto. 1998. "An Ethic of Care." Generations: Journal of American Society on A ging 22(3) (1998): 15-20.

${ }^{14} \mathrm{Ibid}, 16$.

${ }^{15}$ Ibid, 17.

${ }^{16}$ This paragraph has been inspired by what Frankfurt (2008) says about love in pages 79 and 80.

${ }^{17}$ Frankfurt, The Reasons of Love, 80.

${ }^{18}$ Tronto, "An Ethic of Care," 16.

${ }^{19}$ Frankfurt, The Reasons of Love, 95.

${ }^{20} \mathrm{lbid}, 96$.
} 
${ }^{21}$ Rochefoucauld, Collected Maxims and Other Reflections, 5.

22 Peter Kreeft, Christianity for Modern Pagans: Pascal's Pensées Edited, Outlined and Explained (San Francisco. Ignatius Press, 1993), 149.

${ }^{23}$ Tracy, Jessica and Richard Robins, "The Psychological Structure of Pride: A Tale of Two Facets," Journal of Personality and Social Psychology (2007): 506-524.

${ }^{24} \mathrm{Ibid}$.

${ }^{25}$ Simon Blackburn, Mirror, M irror: The Uses and A buses of Self-Love(Princeton: Princeton University Press, 2014), 156.

${ }^{26}$ I mmanuel Kant, Anthropology from a Pragmatic Point of View. Edited by Robert B. Louden (Cambridge:

Cambridge U niversity Press, 2006), 51.

${ }^{27}$ A ristotle, Nicomachean Ethics, 98.

$28 \mathrm{Ibid}, 103$.

${ }^{29}$ Blackburn, Mirror, Mirror: The Uses and A buses of Self-Love, 49.

${ }^{30}$ Frankfurt, The Reasons of Love, 90.

${ }^{31}$ Fromm, The A rt of Loving, 53.

32 Elliot D. Cohen, Logic Based Therapy and Everyday Emotions: A Case-Based Approach, Lanham: Lexington Books, 2016), 34-37.

${ }^{33}$ Elliot D. Cohen, Making Peace with Imperfection: Discover Your Perfectionism Type, End the Cycle of Criticism, and Embrace Self-A cceptance(Oakland: I mpact Publishers, 2019), 24.

${ }^{34} \mathrm{For}$ a detailed explanation of these self-regarding forms of perfectionism, see Cohen (2019)

${ }^{35}$ Elliot D. Cohen, The New Rational Therapy: Thinking Your Way to Serenity, Success, and

Profound Happiness (Lanham: Rowman \&amp; Littlefield, 2007), 16.

${ }^{36}$ Albert Ellis, The Myth of Self-Esteem: How Rational Emotive Behavioral Therapy Can Change

Your Life Forever. (Amherst: Prometheus Books 2005), 19.

${ }^{37}$ Carl R. Rogers, On Becoming A Person: A Therapist's View of Psychotherapy. (Boston: Houghton M ifflin Company, 1995)

38 This quote comes from Lecture 5, page 6, of Dr. Elliot D. Cohen's training lectures.

${ }^{39}$ Protagoras, A Presocratic Reader: Selected Fragments and Testimonia. Edited by Patricia Churchland. Trans.

Richard D. M cKirahan, Jr. (Indianapolis/Cambridge 1996), 98.

${ }^{40}$ Cohen, Making Peace with Imperfection, 115.

${ }^{41}$ Nicolas Bommarito, "Modesty as a Virtue of Attention." The Philosophical Review 122(1) (2013): 103.

42 Tracy, Jessica and Richard Robins, "The Psychological Structure of Pride: A Tale of Two Facets," Journal of Personality and Social Psychology (2007): 506-524. 